\title{
Bettina Marten, Ulrich Reinisch, Michael Korey (eds.): Festungsbau. Geometrie-Technologie-Sublimierung
}

\section{Lukas Verlag, 2012}

\section{Marco Giorgio Bevilacqua}

\begin{abstract}
Marco Giorgio Bevilacqua reviews the collection of papers edited by Bettina Marten, Ulrich Reinisch and Michael Korey, entitled Festungsbau. Geometrie-Technologie-Sublimierung (Fortifications. Geometry-TechnologySublimation), published by Lukas Verlag, Berlin. The book constitutes the proceedings of the conference "Festung im Fokus-Mathematische Methoden der Architectura Militaris des 16. und 17. Jahrhunderts und ihre Sublimierung in der Architectura Civilis", held in Dresden in October 2008.
\end{abstract}

Keywords Military architecture $\cdot$ Fortifications $\cdot$ Geometry $\cdot$ Bastion

M. G. Bevilacqua $(\bowtie)$

DESTeC-Dipartimento di Ingegneria dell'Energia, dei Sistemi, del Territorio e delle Costruzioni, Università di Pisa, Via Diotisalvi, 2, 56126 Pisa, Italy

e-mail: mg.bevilacqua@ing.unipi.it 


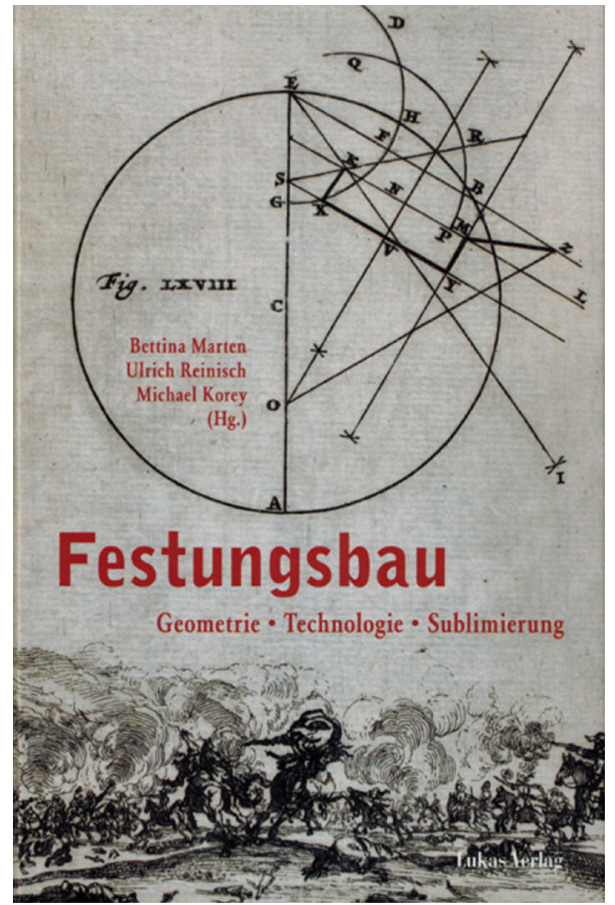

Reviewed by Marco Giorgio Bevilacqua

The collection of papers edited by Bettina Marten, Ulrich Reinisch and Michael Korey is commendable. Their Festungsbau. Geometrie-Technologie-Sublimierung (Fortifications. Geometry-Technology-Sublimation), published by Lukas Verlag, Berlin, constitutes the proceedings of the conference "Festung im FokusMathematische Methoden in der Architectura Militaris des 16. und 17. Jahrhunderts und ihre Sublimierung in der Architectura Civilis", held in Dresden in October 2008.

In this book, the interest in modern fortifications provides an occasion for gathering papers of great value on several topics related to the more complex science of war. Among the authors, we find important names in the field of the history of architecture, mathematics, technical sciences and engineering.

The structure of the book is clear and scientifically consistent. Two texts, respectively "Begrüßung" (Greeting) by Bruno Klein, and "Festung im Spiegel der Wissenschaften. Eine Einführung" ("Fortress in the Mirror of Science. An Introduction") by Bettina Marten, introduce the book and provide the key to understanding the issue. The papers that follow are organized into five thematic sections.

The first section is dedicated to the "Grundlagen des neuzeitlichen Festungsbaus" ("Foundations of modern fortifications"). In "Mathematics and Fortifications. Inheritance and Applications in the Sixteenth Century", Orietta Pedemonte highlights the main topic of the book: the importance of mathematics in the studies 
of fortifications. In "Die Rezeption der Schriften Polybius' und Machiavellis in den Architekturtraktaten von Dürer bis Palladio" ("The reception of the writings of Polybius and Machiavelli in architectural treatises from Dürer to Palladio"), Nicola Aricò provides an interesting study of the references to the Greek historian Polybius (ca. 200 BC-c. 118 BC) and the Renaissance politician Niccolò Machiavelli (1469-1527) in the organization of military camps and strongholds as described in the most important treatises in the sixteenth century.

The section "Medial Aspekte des Festungsbaus" ("Medial Aspects of Fortifications") focuses on the relationship between theory and practice in the geometric definition of fortresses profiles and the derogation to the theoretical principles that often the constructive practice involves. Only two papers are in this section: "Festungsbau und geometrische Praxis" ("Fortification and geometric praxis") by Ralph Gebuhr, and "Die nichtmathematische Festung und ihr medialer Untergang. Eine pluralistische Sicht auf die Geschichte der renaissancezeitlichen Militärarchitektur in Mitteleuropa" ("The non-mathematical fortress and its medial destruction. A pluralistic view of the history of the Renaissance Military Architecture in Central Europe").

The rich third section "Festung zwischen Macht und Technologie" ("Fortification between Power and Technology") comprises six papers. In "Leonardo da Vinci's Military Architecture", Kim Williams analyses several Leonardo's drawings of fortifications from Ms. B of the Institut de France, the Codex Atlanticus of the Biblioteca Ambrosiana in Milan and the Codex Madrid in the Biblioteca Nacional de España in Madrid. In "Naturphilosophie, Mathematik und Handwerk. Buonaiuto Lorini und die Analogie von Maschinenbau und Festungsbaukunst" ("Natural philosophy, Mathematics and Crafts. Buonaiuto Lorini and the analogy of mechanical engineering and fortress architecture"), Tobias Büchi focuses on the relations between mathematics, philosophical sciences and engineering that underlie the art of fortification. In "Neue Festungsstädte in den alten Niederlanden zur Zeit Karls V. und Philips II". (New fortified cities in the old Netherlands at the time of Charles V and Philip II), Bernhard Roosens describes some examples of the new fortified cities founded in Belgium and France in the sixteenth century: Mariembourg, Hesdinfert, Charlemont and Philippeville. In "When the Dagger became a Compass. The Science of Arms and Fortifications", Filippo Camerota discusses various models of compasses dating from the sixteenth century, and in particular those that when closed, become daggers. Issues related to the shooting of firearms and to ballistic applications can be found in "Know how!" by Heiko Berger. Astrid Debold-Kritter concludes the section with "Geometrie und historischer Stadtgrundriss. Die Festung Theresienstadt (Terezín) in Tschechien" ("Geometry and historical city layouts. The fortress of Theresienstadt (Terezín) in the Czech Republic"), an interesting study on the project for the fortifications of Teriezín (Theresienstadt in German) in Bohemia in the late eighteenth century.

The fourth section "Festung zwischen theoretischer und praktischer Geometrie" ("Fortifications between theoretical and practical Geometry") is dedicated to the relationship between theory and military practice. The various aspects with which the topic may be declined are introduced in "Theoria et Praxis Architecturae Militaris. Ein Missverständnis der Festungsbaukunst" ("Theory and praxis of the 
Military Architecture. A misunderstanding of fortress architecture") by Stefan Bürger. In "Missing the target. The Cautionary Tale of a Ballistic Misreading", Michael Korey mainly focuses on the interpretation of a drawing by Paul Pucher showing the range of a mortar fired at three elevations (Dresden, 1577, Mathematisch-Physikalischer Salon, Staatliche Kunstsammlungen). In "Galilei als Militär. Der Streifschuss und die Geometrie des Auges" ("Galileo as a soldier. The grazing fire and the geometry of the eyes"), Horst Bredekamp offers an interesting research on Galileo Galilei's treatise of fortifications. In "Safe strongholds. Mathematical Fortification and the Fortress of Mathematics", Jeroen Goudeau focuses on some treatises of military architecture, underlining how from the seventeenth century onward two shifts of attention can be discerned: the first, the move from a more practical towards an even more theoretical approach in the design of fortifications; the second, the move from symbolic view on the theory of fortification to a technical and encyclopaedic disposition. "Fortification and mathematics in early modern England: Notes toward a Cultural History" by Stephen Johnston, take us to England, with the study of several treatises from the sixteenth to the eighteenth century, including those of Paul Ive, Richard Norwood and Sir Jonas Moore up to Ephraim Chambers's Cyclopaedia. In "Von der »trigonometrischen Festung « zur »Ingenieur-Wissenschaft « Bélidors" ("From the 'trigonometric fortress' to Bélidor's 'engineer-scholar'”), Stefan Holzer highlights the importance of trigonometry in the education of men of arms, focusing on the figure of the French engineer Bernard Forest de Bélidor.

The fifth and final section, entitled "Strategien der Sublimierung und Kulturierung" ("Strategies of sublimation and culturalization") is composed of four papers. The first, "Angst, Rationalisierung und Sublimierung. Die Konstruktion der bastionierten, regulären Festung als Abwehr von Angstzuständen" ("Fear, rationalization and sublimation. The construction of the regular bastioned fortress as defence against states of anxiety") by Ulrich Reinisch, has an original psychological slant. Judith Schleret in "Von der place d'armes zur Place Royale" ("From the military square to the royal square") analyses the theme of the military square, the staging ground for military events, in the wider context of the Renaissance and Baroque urban design. "Die Kugel in der Mauer. Zur semantischen Aufrüstung von Fassaden in der Renaissance" ("The ball in the wall. For a semantic armament of facades in the Renaissance") by Marion Hilliges, focuses on the symbolic use of cannon balls as decorative elements in the façades of civil and military buildings in the Renaissance. The section ends with an interesting research by Christof Baier on boxwood bastions: "Architectura Militaris in der Gartenkunst des 17. und 18. Jahrhunderts, dargestellt am Beispiel des Gartens in Enghien und der gartentheoretischen Schriften von Stephen Switzer" ("Architectura Militaris in the garden art of the seventeenth and eighteenth century, exemplified by the gardens at Enghien and the garden theory writings of Stephen Switzer"), the author shows how the principles of military architecture were applied to the garden design between the seventeenth and eighteenth centuries.

As the reader can see, several topics are covered: from the theoretical rules for tracing the modern bastion front to the related development of the mathematical and physical sciences; from the practice of construction to the tools for soldiers and 
military engineers; from Renaissance urban design and its relation with the requirements of war, to the aesthetic aspects that remain in an architecture that was increasingly being defining as a response to purely functional and technical requirements. Each paper refers to the most current bibliography and to the most important specialized treatises from the fifteenth to the eighteenth century in Europe. Some of the research also regards specific examples of fortifications in Europe. The whole is richly illustrated with an abundance of colour figures.

The constant reference to mathematics and geometry as the foundation of the modern science of fortifications, is the "common denominator" of all the texts. This allows us to recommend Festungsbau to all readers of this special issue of the Nexus Network Journal dedicated to military architecture and mathematics, which offers an ulterior deepening of the topics covered in the rich volume edited by Marten, Reinisch and Korey.

The only limit of this volume is that almost all the papers are written in German; this makes much of the book difficult to read in an international context.

Marco Giorgio Bevilacqua is Assistant Professor of Architectural Representation at the University of Pisa, where he was graduated in 2003 and received a Ph.D. in "Sciences and techniques for the civil constructions" in 2008. His research interests are in the field of valorization of the historical architectural heritage, with particular attention to historical military architecture, architectural and urban survey and digital technologies for the communication of historical architectural heritage. He currently teaches Architectural Representation and Methodologies for Architectural surveying in the Master degree program of Building Engineering and Architecture. He has published several works and papers on his main research topics, presented conferences and lectures. Among his publications are Le mura di Pisa. Rafforzamenti, ammodernamenti e modificazioni dal XII al XIX secolo, co-authored with Cristina Salotti (Pisa: ETS, 2011); for the NNJ "The Conception of Ramparts in the Sixteenth Century: Architecture, 'Mathematics' and Urban Design" (NNJ 9, 2 (2007), pp. 249-261), "The Turkish Baths in Elbasan: Architecture, Geometry and Wellbeing" with Roberto Castiglia (NNJ 10, 2 (2008), pp. 307-321297-313) and "Alexander Klein and the Existenzminimum: A 'Scientific' Approach to Design Techniques" (NNJ 13, 2 (2011), pp.). He is co-author with Kim Williams of "Leon Battista Alberti's Bombard Problem in Ludi matematici: Geometry and Warfare" (The Mathematical Intelligencer, 34, 8 (2013), pp. 27-38). 